Discourse and Communication for Sustainable Education, vol. 10, no. 2, pp. 112-128, 2019

\title{
The Effects of Preschoolers' Media Usage Habits on Their Daily Life and Sustainability
}

\author{
Begum Canaslan Akyar \\ Tarsus University, Mersin, Turkey \\ Özkan Sapsaglam \\ Yildiz Technical University, Istanbul, Turkey
}

\begin{abstract}
Today's children are born into a digital world and are exposed to various electronic devices and digital contents both in the home environment and other environments since the first years of life. Children, who are a natural recipient of the environment in which they live, are exposed to the effects of the digital world at different levels and reflect these effects in different ways. The purpose of the reported study is to investigate if preschoolers' daily media usage habits affects their drawings. This study is planned according to the case study design of qualitative research methods. The study was conducted with 15 preschoolers and their parents. There were nine boys and six girls in the study. The preschoolers' drawings and their parents' interview data were analyzed by using the descriptive analyzing method. The study result shows that there are differences between boys and girls media usage habits. Boys spend more time with media tools than girls. Additionally, boys are exposed to more inappropriate content because of their preferences. The analysis of their drawings revealed that boys are more affected than girls from media contents since boys' drawings include more characters from media than girls. It can thus be suggested that media tools might be harmful when they are used in a developmentally inappropriate way, and excessive media tool usage has negative impact on children. Therefore, the reported study recommends that parents and caregivers take some precautions to limit preschoolers from spending time with media tools and to control content of children's activity.
\end{abstract}

Key words: preschooler, media, drawings, early childhood, consuming behavior, sustainability.

\section{Introduction}

The impact of early childhood on children's future lives is now a recognized reality in the world, and the family environment in which this period is spent is the child's first source of knowledge and experience (Sapsaglam, 2018). Digital technologies and appliances are rapidly expanding in homes and other environments (Arnott, 2013). Using media tools age is decreasing day by day. $52 \%$ of children who are from 0 to 8 years old 
could access mobile devices in USA (Rideout, 2011). The number increased by $75 \%$, children who are between 0- and 8-years old accessibility of mobile devices in 2013 (Rideout, 2013). In 2017, the report which was conducted in USA, stated that $42 \%$ of children have their own private tablet and they spend around two hours and fifteen minutes a day with media tools (Rideout, 2017). Infants and toddlers start media usage at three and five months (Valkenburg \& Piotrowski, 2017). While increasing the children's rate of media tools usage, adults should be careful to prevent children excessive exposure of passive and nonsocial technology use (AAP, 2016). Caregivers and teachers should arrange tools and programs to encourage children's playful explorations because carefully selected programs support children to be active, and understand the world around them (Moore, 2017). Especially, early childhood educators find culturally responsive and developmentally appropriate way for sharing technology and digital tools (Donahue \& Schomburg, 2017).

Media tool is not always harmful when the use of media tool is controlled. Previous studies have reported that, appropriately designed media content provides interactive learning, improve their skills and healthy development (Thai et al., 2009). Furthermore, developmentally appropriate media content contributed to children's both cognitive, such as literacy and numeracy, and social-emotional development such as friendliness, sharing and acceptance of diversity (Courage \& Howe, 2010). Seemingly, there is a positive relation between playing video game and creativity. Verenikina and Kervin (2011) stated that using tablet by under five-year old has positive impact on children's creativity According to the study, children who were 12 years old and who played more video games were significantly more creative than children who played less video games (Jackson, 2012). In addition, in the same study, parents reported that applications (apps) were promoting their children's play and creativity. Apps provided children's in-text and drawing creativity skills. By using apps, children could write, draw, paint and create collages (Marsh et al., 2015). However, parent's supervisor role is important for introducing new apps, which enhance creativity and play (Marsh et al., 2015).

Beside these negative impacts, many of the media contents are not evaluated in terms of their appropriateness for children's development (Lieberman, Bates, \& So, 2009). The uncontrolled, very poorly designed media contents are harmful to children because they are directed to children's aggressive and anti-social behavior by role modeling, rewarding and teaching. In addition, the inappropriate content indoctrinates to children fear and anxiety as well as identifying and ignoring ethnic and gender stereotypes (Lieberman, Fisk, \& Biely, 2009).

The sustainability interpretations are available in contexts of different scientific spheres: economics, ecology, psychology, philosophy, art and social sciences (Slušnienè, 2019; Salite, 2015; Fedosejeva et al., 2018). World Commission on Environment and Development (WCED) defined sustainable development as “...development is development that meets the needs of the present without compromising the ability of future generations to meet their own needs" (WCED, 1987, p. 37). Sustainable development is believed to consist of three dimensions: the protection of the natural environment, the maintenance of economic vitality, and the observance of specific social considerations (Veisson \& Kabadayi, 2018). Consumption is the largest problem for global sustainability for rich countries (Baudrillard, 1998). To deal with these problems, early childhood years are a vital period for the introduction of sustainability (United Nation's Educational Scientific and Cultural Organizations (UNESCO, 2008). The early year sustainability 
awareness could be related to everyday behaviors, for instance, bathing, laundering, or the use of modern technological devices (Shove, 2003).

Digital media tools have changed children's consumption behaviors. Media is a source of information which has an effect on people's knowledge of environment and attitudes (Keinonen et al., 2014). Digital media can be accepted as one of the children's part of environment. According to socio-ecological perspective, which is drawn by Bronfenbrenner in 1986 mentions the children's development and environment relationship. Additionally, Lee, Bartolic, and Vandewater (2009) recognize the media context in the socio-ecologic perspective. The media elements of macrosystem could be linked with children's core values and beliefs towards environment via affect consumer choices (Skouteris, Do, Rutherford, Cutter-Mackenzie, \& Edwards, 2010). Lindstrom and Seybold (2003) suggest that children have an excessive effect on family's expenditure. A study shows that there is a positive relationship between increasing TV times and 36-year-old children's decision of branch while shopping with their family (Kirdar, 2007).

Digital games are another way of effecting children's consumer behavior. The consumerism behavior is emphasized in different ways like adverb-game and in-game advertising (Kusay \& Akbayir, 2015). Therefore, the content of programs for children is very important. The messages conveyed by programs have the potential to influence children's perceptions and behaviors. For an ecologically and sociologically sustainable life, television programs can be used as a tool and can raise awareness for both children and parents. However, television programs often do not have such a concern and programs do not reach the masses (Bilgic, 2016). An example of this is public service broadcasting published at a time when the rate of audience is low. Tek and Ozgul (2013) stated that in order for the broadcasts to inform and raise public awareness, the necessity of broadcasting public spots on all television channels should be made and these broadcasts should be made within reachable hours (as cited in Bilgic, 2016). Consumers are becoming more aware of the fact that, through media, an altruistic ethical or environmental concern as well as greater enjoyment of quality, organic food or cycling for work motivates the reception of environmentally preferred behaviors (Soper, 2007). Internet, e-mail, television programs, documentaries and advertisements can be used for more sustainable consumption (Holbert, Kwak, \& Shah, 2003).

Excessive media tools usage causes some problems. In a study, parents reported that excessive media habits lead to difficult behaviors like difficult temperament (Thompson, Adair, \& Bentley, 2013) or self-regulation problems (Radesky, Silverstein, Zuckerman et al., 2014). A study which was conducted at Korea with children found that high level of computer use causes low socio-emotional development score. In this study, children who spent more time with TV got low score from socio-emotional test (Seo et al., 2011). In addition, the other study mentioned that electronic media use and physical activity during early childhood period might be related to psychosocial health (Teychenne, Ball, \& Salmon, 2012). If the psychosocial development is disturbed by for instance media tools, children can have problems about reading faces, basic communication, and relationship skills. Children who excessively watch TV tend to have to cope with social problems and they are less active during weekend and consume more snacks than children who spend less time in front of the TV (Pagani et al., 2010). Besides psychosocial development, there is an association between violent media content and aggressive behavior of children (Christakis, 2016) because children imitate what they see on screen and they reflect this kind of behavior in frightening content (Radesky \& Christakis, 2016). 
Boys are more likely affected by the violent content. In the early childhood period, boys and girls have different preferences, for instance, boys tend to like sports, action, and violence concepts for both media tools and books. Moreover, scary scenarios such as dinosaurs or alien fantasy heroes and superpower characters might be their favorite (Valkenburg \& Piotrowski, 2017). On the other hand, girls generally are interested in nurturing themes. Dancer, fairies, and princesses are their favorite characters (Valkenburg \& Piotrowski, 2017). For this reason, studies have presented that boys select aggressive play like imaginary fights or battles, rowdy sports, roughhousing and aggressive play. On the contrary, girls prefer requiring fine motor skills play such as designing jewelry, handicrafts, or dressing dolls (Valkenburg \& Piotrowski, 2017).

Some countries like the United States, Canada, and Australia officially do not support the use of screen media for children who are under 18-month-old. Additionally, France does not allow TV stations from airing a program which aims children who are under three years old (Valkenburg \& Piotrowski, 2017). Some researchers argue that media tools improve children's learning, on the contrary, a study shows that children who are less than 30 months of age, cannot learn new information without any adult supporting with real-life experiences (Dickerson, Gerhardstein, Zack, \& Bar, 2013). Furthermore, children who are less than 2.5 years old cannot learn new words from videos if an adult does not repeat or use the same words in their daily interactions (Richert, Robb, Fender, \& Wartella, 2010).

When considering children's developmental features, children's drawings give important clues about children's inner world. Drawing is a reflective way of children's emotions and thoughts across events around them, inner world, and cognitive development (Saglam, 2011). In addition, children's drawings give clue about their personality (Striker, 2005). In short, drawing is not only a pleasurable activity for children, but also a tool for expressing themselves (Hayes, Symington, \& Martin, 1994) regarding emotion, feeling, thought, culture, opinion, values, personality and their inner world (Buyurgan \& Buyurgan, 2007; Lin, 2006; Malchiodi, 2005; Sapsaglam, 2017).

The usage of the children's media tools should be carefully monitored by adults to protect children's both excessive exposure and inappropriate content for their development (AAP, 2016; Donahue \& Schomburg, 2017). Excessive media tool usage leads to some social problems (Thompson, Adair, \& Bentley, 2013; Radesky, Silverstein, Zuckerman et al., 2014; Seo et al., 2011). Especially, violent content has negative effect on boys because violent content tends to be more interesting for boys (Valkenburg \& Piotrowski, 2017). Digital media is in the middle of young children's life. The researchers believe that explaining the impact of digital media on children is important for all development. Children can reflect themselves by drawing and drawing is a tool of understanding young children's inner world. The aim of the study is to determine whether the characters drawn by children are affected by digital media and to compare the drawings of boys and girls. Additionally, knowing their daily digital media tools habits are vital for the study in order to explain the media effect on children's drawings. For this reason, parent interviews help examining the drawings in a frame. It is thought that the study is important in terms of the absence of a previous research in this regard and the findings of the research. In this frame, the researchers ask the following questions:

- How many hour children spend time with digital media tools?

- Has digital media impact on children's behavior? 
- Does digital media effect boys' creative drawing?

- Does digital media tools effect girls' creative drawing?

\section{Research Methods}

This study was planned according to the case study design of qualitative research methods. The study was carried out in the spring semester of 2017-2018. The case study is a useful strategy to examine the current situation is related to which factor(s). In addition, how the factor affects or is affected by the situation is investigated (Yildirim \& Simsek, 2013). In this research, using case study was appropriate because the study focuses on the children's daily media usage at their natural environment.

\section{Participants}

The study group was selected based on homogenous sampling method. The study group is formed by 60-66-month-old children who enrolled in early childhood education and their parents. There were nine boys and six girls in the study group. These children were selected from a public pre-school is in the Tokat district in the Middle Black Sea. In order to obey ethical rules, and follow privacy policy, code numbers were given to children and their parents.

\section{Data Collection Instruments}

Children's drawings and semi-structured interview were used to gather data. In this regard, data collection and data sources are differentiated. The children closed their eyes, thought a character, and then the researcher asked to the children to draw this character on a blank sheet of paper. Then, each interpreted their own drawings, and the researcher took notes. In order to support the children's drawings analysis, parent interviews were conducted to have knowledge about the using media habits of the children. The semi-structured interview form was created by the researcher and arranged after an expert opinion. The first part is for demographic information and the second part of the form is about children's daily habit of screen-based devices and contains 14 items. Before conducting the interviews, the participants were informed about the purpose of the study, volunteer participation and right to withdraw whenever they wanted. In addition, the researcher mentioned voice recorder. The parent interviews were generally conducted at the school before picking up and after dropping their children in a silent and isolated room for children and adults. Each interview took almost 20 minutes.

\section{Data Analysis}

The children's drawings were analyzed by content analysis. In addition, the interviews were firstly listened again and then transcribed. After transcribing the data set, these were analyzed by using the descriptive analyzing method. According to the descriptive analyzing method, the aim is to analyze data by a summary and interpretation (Yildirim \& Simsek, 2013). 


\section{Research Findings}

The characteristics of the children's parents and their home situation regarding technological devices were firstly mentioned. The parents' using social media frequency is changed between half an hour and four hours in a day. In addition, all the children have a TV and smart phone at their home, then tablet is most reachable media devices $(\mathrm{n}=10)$ and some children have a PC $(\mathrm{n}=9)$ at their home.

\section{The Usage of Media Tools}

According to the result of the data analysis, one of the themes is the usage of media tools. The theme has sub-themes which are the total hours of using media tools and type of activity. Figure 1 shows the themes.

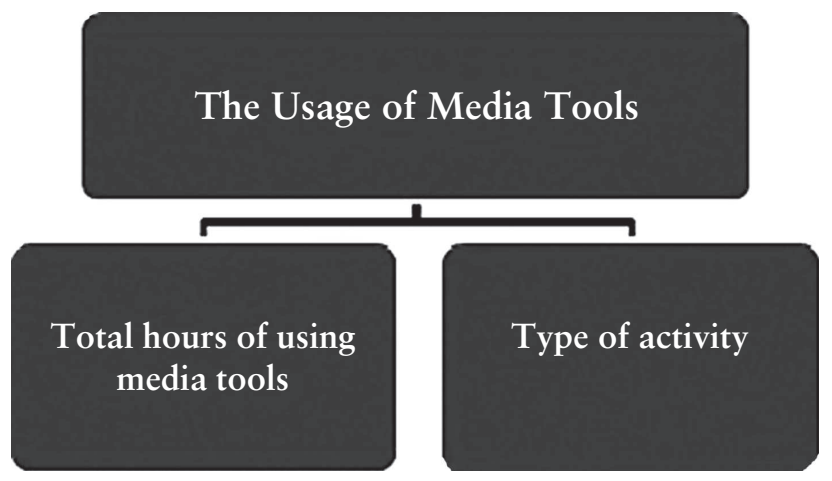

Figure 1. The children's usage of media tools

Figure 1 includes themes related to the use of media tools. When the findings are examined, two important themes emerge. The first theme is related to the use of media tools and the second theme is related to the type of activity. The descriptive statements of parents on these themes are given below.

When analyzing the codes, the most emphasized point is that all children spend their time with media tools. The time interval is changed between 30 minutes to more than four hours. The table 1 demonstrates the children's total hours of media tools usage. According to the responses of the parents the boys are spending more time than girls with media tools. The girls generally spend time in 30 minutes to one-hour interval. However, the boys are generally in two hours to more than four hours' interval. In this context, one of the mothers (P11) stated that:

"He is spending time around totally four hours with a mobile phone. I allow him to play with mobile phone because he says that he could not play with it when he was at school"

The mother emphasized that the four hours is with a break, the child plays with media tools in a different time frame in a day. The other mother (P2) stated that

"Sometimes it takes longer than two to three hours. If I do not warn him or take away the mobile phone from him, he does not leave it." 
However, some children do not stop using media tools, therefore, mothers put limit, or they have to take the tool from their children."

Table 1

Total Hours of Using Media Tools

\begin{tabular}{cc}
\hline Time & $f$ \\
\hline 30 mins $-120 \mathrm{mins}$ & 9 \\
\hline $121 \mathrm{mins}-240 \mathrm{mins}$ & 4 \\
\hline $240+$ & 3 \\
\hline
\end{tabular}

The children's type of activity with media tools was deeply investigated in the study. Most of the parents stated that children play games with the media tools. In addition, children prefer watching video via YouTube. Table 2 shows the children's type of activity with media tools. Even children do not play a real game, they are watching videos which the content of the video is playing game or describing a video game. There are differences between boys and girls in the type of activity with media tools. The girls are mostly watching video with the media tools. In addition, they are interested in princess, do it yourself or something which is related to daily life. P1 stated that

"She watches videos via YouTube, she is watching making play dough, or assembling Kinder surprise's pieces of toys."

The other mother $(\mathrm{P} 3)$ reported that

"She watches cartoon videos or videos which children are playing games on it. Sometimes, she watches videos related to wedlock."

On the other hand, the boys prefer to watch or play about war, zombie, or something which contains violence. P9 pointed out that

"He watches a video which name is GTA 5, if there is an internet connection.

If there is no internet access, he plays car race game."

In addition, P15 stated that

"He played nonstop a Zombie Catching game, he did not hear us, and he was

looking meaningless anymore, I banned playing with the media tool for fifteen days.”

It can be said that the children, especially the boys do not play appropriate game regarding their age.

Table 2

Type of Activity

\begin{tabular}{cc}
\hline Activities & $f$ \\
\hline Playing game & 8 \\
\hline Watching video & 6 \\
\hline Watching cartoon & 1 \\
\hline
\end{tabular}




\section{Effects of Media}

The other theme is the effects of media tool on children based on the analysis of the study, behavioral effects and domestic problems.

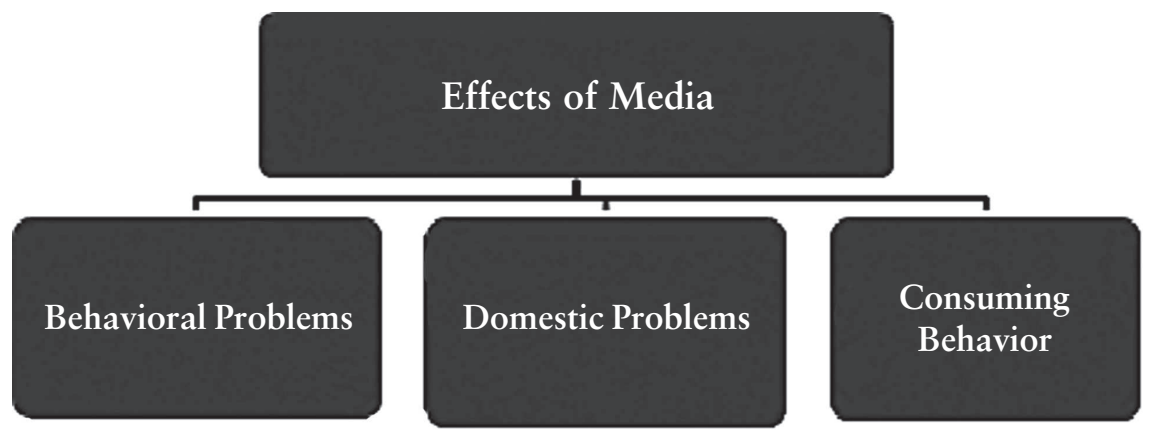

Figure 2. Effects of media on children's life

Figure 2 indicates themes related to the effects of media tools. When the findings are examined, three important themes emerge. The first theme is related to behavioral problems, the second theme is related to domestic problems of use of media tools, the third theme is related to consuming behavior. The descriptive statements of parents on these themes are given below.

When analyzing the parents' responses, most of them stated that children reflect the effect of media tools on their behavior. In addition, the parents mentioned only negative effect of the media tools. The table 3 presents the behavioral effect of media on children. The boys are further affected than girls from the media tools according to parents' report. For instance, P6 stated that

"Sometimes he wakes up in fear and screams as saying mother! I do not know the source of the fear that the games which he plays in tablet or the cartoons which he watches on TV. However, I believe that cartoons can affect him more because he usually more watches cartoon than plays with tablet."

P13 pointed out that

"He cannot realize the danger, he cannot understand that danger is danger. He says that it was just a game. He harms his sibling because he thinks that it is a game."

The exemplary quotas explain the relationship between the boys' activities and effects on their behavior.

Table 3

Reflecting on Behavior

\begin{tabular}{cl}
\hline Responses & $f$ \\
\hline Equate themselves with media characters & 3 \\
\hline Tend to violence & 2 \\
\hline Fear from something & 2 \\
\hline Use bad words & 1 \\
\hline Desensitization & 1 \\
\hline
\end{tabular}


The media tools cause some problem at home, as well, according to parents. Most of the children decide what they are going to do with the media tools. However, sometimes the content of the videos or games are not appropriate in the parents' opinion. For this reason, the parents and children cannot compromise, and they have chaos at home. P4 stated that

"He is offensive and aggressive if I intervene his play."

In addition, parents reported that the siblings are fighting because no one wants to give the media tools to another. P15 emphasized that

"He has sisters, they do not deal with the games. Because the girls want game for girls, and he wants to download games for boys. They are fighting for this reason."

Table 4

Domestic Problems

\begin{tabular}{cl}
\hline Problems & $f$ \\
\hline Disagreement about content & 3 \\
\hline Fratricidal quarrels & 2 \\
\hline Eating separately & 1 \\
\hline Getting stubborn & 1 \\
\hline Showing aggressive behavior & 1 \\
\hline Demoralized & 1 \\
\hline
\end{tabular}

The last theme is about consuming behavior of children. According to parent's reports, these children mostly are impacted by digital media regarding consuming behaviors. The children's meal preferences, clothes, and toy preferences were asked to their parents. The answers show that children prefer eating Turkish dinner, meatball, and rice. In addition, most of the children do not have any persistence on digital media character on their clothes and toy preferences. On the other hand, some of them want a hero or popular characters on their clothes. For example, P7 stated that;

"He usually prefers to wear Spiderman t-shirts as clothes."

Additionally, a mother stated that digital media characters are a key factor of toy selection for her daughter. M14;

"She likes playing with dolls; therefore, she wants to buy dolls generally.

Especially if she sees the character's doll, she persistence to buy the toy."

Table 5

Consuming Behavior

\begin{tabular}{cc}
\hline Type of consuming & $f$ \\
\hline Toys & 2 \\
\hline Clothes & 2 \\
\hline Meal & 2 \\
\hline
\end{tabular}




\section{Children's Drawings}

The character drawings of girls and boys were analyzed by their verbal transmissions and evaluation of the pictures. The findings are given below.

\section{Boys' Drawings}

When the pictures drawn by boys were examined, their characters were exposed through digital media appearing in the direction of their explanations. Boys have drawn characters like superheroes, dinosaurs, knights, weapons, such as war and in the drawings. A few examples of the character drawings made by children are as follows

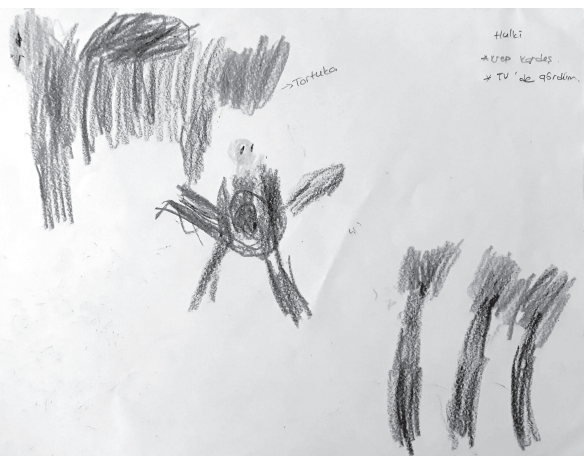

Figure 1. C9's cartoon affected character

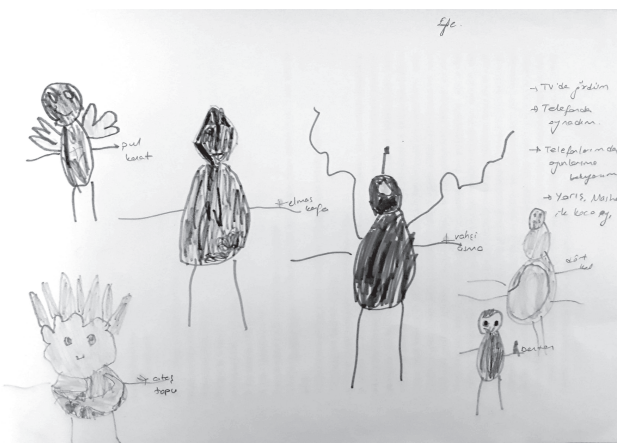

Figure 3. C7's cartoon affected characters

Figure 4. C13 cartoon affected character

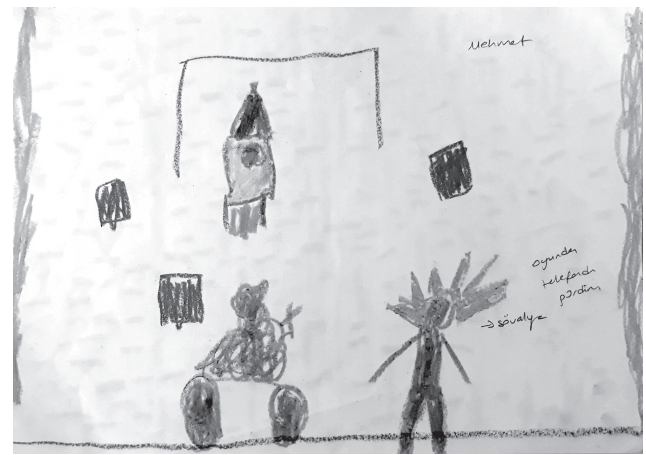

Figure 2. C11's game affected character

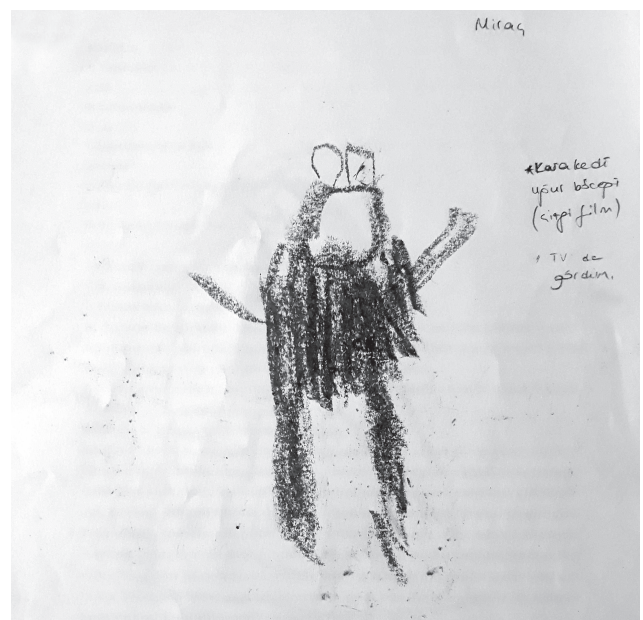

In the drawing of the participant, C9, he said that he had drawn the character of Tortuka, which he saw in the Kratt brothers' cartoons in Figure 1.

The participants, C11, explained that he depicts the knight character shown in Figure 2, which he saw while playing a game on mobile phone.

In the drawing shown in Figure 3, participants, C7, explained that he drew the characters of Ben10, which he saw both in TV and game.

One of the children, C13, depicted the character Ugur Bocegi, which was shown in Figure 4 , in the picture he made in a television cartoon. 


\section{Girls’ Drawing}

When the drawings of girls are examined, it is revealed that the pictures they made contain more princess figures. In addition, children reflect what they see in daily life in their drawings is another finding according to the children's expressions. A few examples of children's drawings are given below.

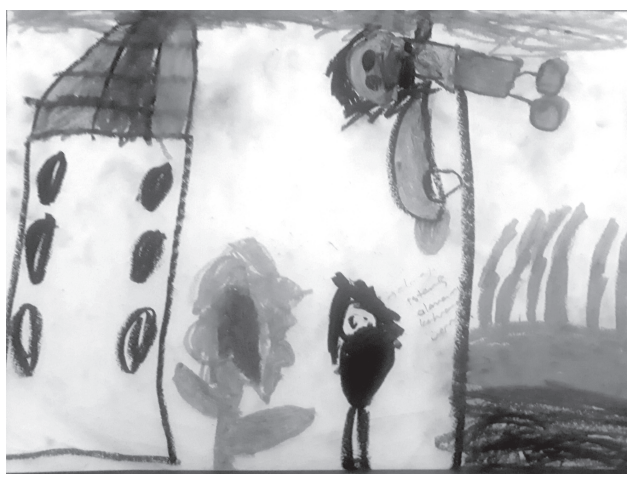

Figure 5. C10 character drawing

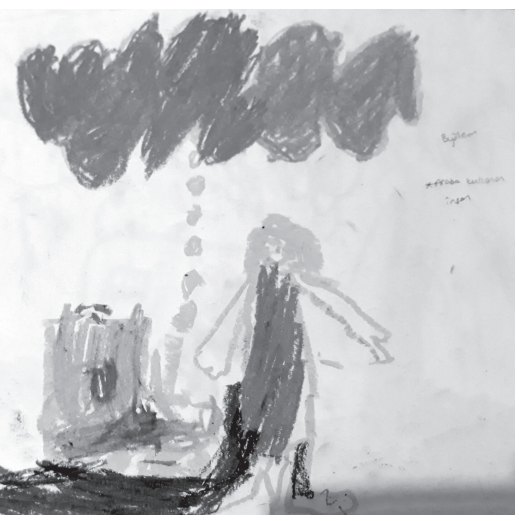

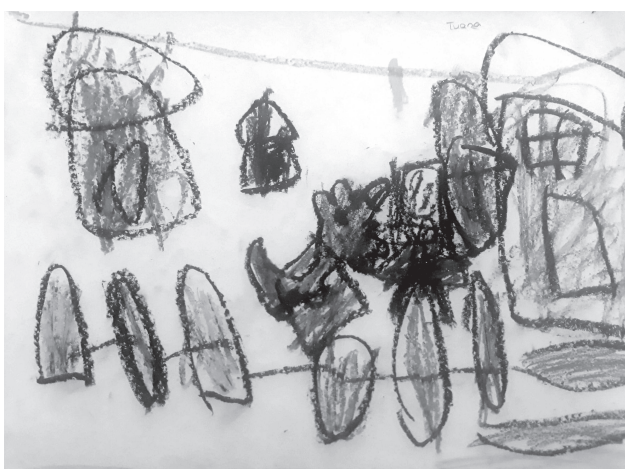

Figure 6. C13 character drawing

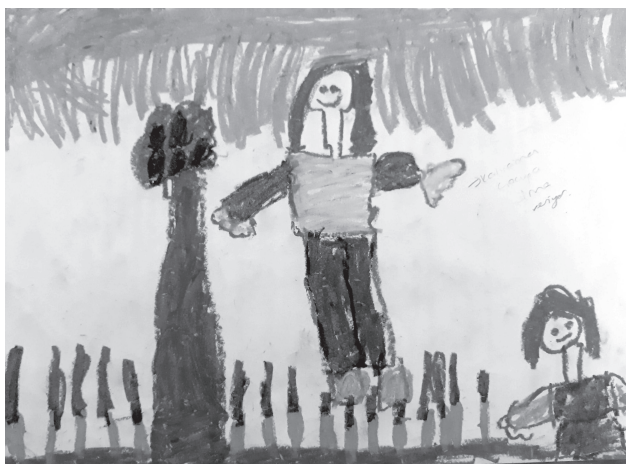

Figure 8. C14 character drawing

Figure 7. C3 character drawing

In the drawing shown in Picture 5, the child, C10, drew a garden. There is a girl in the garden. She would like to take an apple from a tree, but she can't. Then a super hero came and gave the apple to the girl.

One of the children (C13) depicted that princes and her dog. They have a walk. She added that she saw them in her dream.

In Figure 7, the child, C3, explained that there is a person who is driving a car. She see them around every day.

One of the children (C14), drew a superhero. The superhero is giving an apple to the child. 


\section{Research Findings}

The aim of the study is to determine whether the characters drawn by children are affected by digital media and to compare the drawings of boys and girls. The study was constructed on the case study design of qualitative research methods. Purposive sampling and homogeneous sampling methods were used to form the study group. The obtained data were analyzed by descriptive analysis technique, according to the result of the research.

All the children had at least two media tools in their home. TV and mobile phone are the most common digital media tools which are accessible by children. In addition, most of them have also tablet and PC in their homes. Our findings confirm Vandewater et al. (2007) results, they stated that children are born and grown in media-saturated environment. Accessing and using of any media tool became part of their daily life (Vandewater et al., 2007). Because they are surrounded by the media tools, as usual, they spend much time with them. Previous research has detected that the common media tool preferred by children is dominantly television. Even children play with video games or use computer, they play around under one hour (Vandewater et al., 2007). On the contrary, the current study results demonstrate that children spend most of their time with mobile phone, tablet and then television. Especially boys allow more than two hours for media tools.

Today's children do not use mobile phone or tablets for only playing games, they frequently watch videos via YouTube if internet connection is available. Even the child does not know reading and writing, they can find whatever they want to watch. One of the study states that media tools take away children from hands-on play, although the hands-on play is controlled and generated by children throughout their interest (Vibbert \& Meringof, 1981). There is concern that digital play causes decreasing spontaneous and traditional forms of play (Brown, 2009). However, not only spontaneous and traditional type of play, even digital play might be under a risk, because children watch videos and the videos' topics are play. The children watch other children's play rather than play their game.

The content of the media tools which children are exposed to is important as well. Based on the result of the current study, children, especially boys are not exposed to appropriate content. They are prone to play war, zombie games, containing bad word videos. This result fits well with very poorly designed games that can teach, model or reward aggressive behavior, instill fear and anxiety (Christakis \& Zimmerman, 2009). The very poor content causes violent behavior, being afraid and not aware of harmful behaviors. American Academy of Pediatrics Council on Communications discussed that media violence related to aggression, lack of empathy and desensitization to violence (2009). Accordingly, the media devices cause poor social competence, social withdrawal and poor communication skills (Ebbeck, Yim, Chan, \& Goh, 2015). As stated in the current study, the children have problems with their siblings and sometimes with their parents, especially mothers, because of media tools. Additionally, digital media tools affect children's consumer choices (Skouteris et al., 2010). However, children have not been affected by digital media tools regarding consumer choices. This interpretation contrasts with that of Kirdar (2007), stated that there is a relationship between increasing screen time and decision of branch while shopping with their family.

Finally, media tools limit children's creativity and predetermined responses (Haugland \& Wright, 1997). Similarly, with the Haugland and Wright's study, the current study shows that exposure to prolonged hour media tools decrease creativity. However, 
the findings of the current study, are inconsistent with the literature mentioned before. For instance, in the literature review part, Jackson (2012) argues that children who played game long hours have higher creativity score. In the current study, the children who spend more time with media tools, drew only characters from the media tools. On the other hand, the children who spend less time with media tools, drew more independent characters from media tools.

Monitoring by an adult is important for controlling the content of the media and setting time limits (Campaign for a Commercial-Free Childhood. Alliance for Childhood, \& Teachers Resisting Unhealthy Children's Entertainment, 2012). Therefore, children are required to be warned by someone to limit themselves in terms of spending long hours in front of any media tools. A study which was conducted at 2013, stated that mostly mothers decided what children do with media tools, then children and finally fathers decided (Álvarez, Torres et al., 2013). On the other side, today most of the time children decide what to do with media tools. However, children are not mature enough to decide what content is appropriate themselves. For this reason, parents are aware of possible risks of media tools like cyber-bullying, sexual overtures or threats to privacy have negative effect on children social development (Livingstone et al., 2011)

\section{Conclusions}

The study reveals that boys allow more time than girls to media tools. The children reflect effect of digital media contents on their behavior. For example, they face violent behavior, having fears, and desensitization. Additionally, the study shows that boys are exposed to inappropriate content for their development. Besides boys, girls spend less time with media tools and they consume more appropriate content for their development. There are variety of content and activities which children can access. In the study, the children spend time with YouTube. Additionally, children are not negatively affected from digital media tools regarding consuming behavior. Parents report that their children do not insist of any brands in costume, food or toys. The children consume more traditional foods, and they decide costume with their parent. Therefore, it could be said that digital media may not impact children's consuming behavior.

Based on their parents' reports, most of them do not watch inappropriate content. Although some parents ban them, some children still watch. The children's drawings reveal that the boys' drawings had more under effect of media tools. As parents' reporting, the drawings show that boys are highly exposed to digital media tools. Therefore, boys' creative drawings contain much digital media sign than girls' creative drawing. The negative effects of media tools are widely known, however, limiting time and decreasing children's spending time with media tools are out of the question.

\section{Implications for Practice}

It can thus be suggested that, parents can resist children's desire to play with media tools. Similarly, Teichert (2017) suggested that parents and caregivers limit children's screen time because they are concerned for children's physical and social development. Furthermore, the increasing time of spending with digital media tools could lead to increase children's consuming behavior. The children can tend to consume well-known branches and plastic packet foods, etc. For this reason, a future study can analyze the 
relation between children's screen times and type of branches that they show behavior tendency. The parents also can put rules and do not flex these rules. Again, the same study mentioned that parents set a rule as children can use media tools only with a parent (Teichert, 2017).

\section{References}

AAP (American Academy of Pediatrics) Council on communications and media. (2016). Media and young minds. Pediatrics, 138(5), 1012. Retrieved from http://pediatrics. aappublications.org/content/pediatrics/early/2016/10/19/peds.2016-2591.full.pdf

AAP Council on Communications and Media. (2016). Virtual violence policy statement. Pediatrics, in press.

Álvarez, M., Torres, A., Rodríguez, E., Padilla, S., \& Rodrigo M. J. (2013). Attitudes and parenting dimensions in parents' regulation of Internet use by primary and secondary school children. Computers \& Education, 67, 69-78.

American Academy of Pediatrics Council on Communications. (2009). Media violence. Pediatrics, 124, 1495-1503.

Arnott, B., \& Brown, A. (2013). An exploration of parenting behaviors and attitudes during early infancy: Association with Maternal and infant characteristics. Infant and Child Development, 22(4), 349-361.

Arnott, L. (2013). Are we allowed to blink? Young children's leadership and ownership while mediating interactions around technologies. International Journal of Early Years Education, 21(1), p. 97-115.

Baudrillard, J. (1998). The consumer society: myths and structures. London, UK: Sage. Bilgic, B. (2016). Process of formation of public service announcement in turkey and broadcasting policies. The Journal of Communication Studies, 1(2), 25-61.

Brown, S. (2009). Play: How it shapes the brain, opens the imagination, and invigorates the soul. New York: Avery.

Buyurgan, S., \& Buyurgan, U. (2007). Art education and managing (2 ${ }^{\text {nd }}$ ed.). Ankara: Pegem Academy.

Campaign for a Commercial-Free Childhood. Alliance for Childhood \& Teachers Resisting Unhealthy Children's Entertainment. (2012). Facing the screen dilemma: Young children technology and early education. Boston, MA: Campaign for a CommercialFree Childhood: New York: Alliance for Childhood.

Christakis, D. A., \& Zimmerman, F. J. (2009). Young children and media: Limitations of current knowledge and future directions for research. American Behavioral Scientist, 52(8), 1177-1185.

Courage, M., \& Howe, M. (2010). To watch or not to watch: Infants and toddlers in a brave new electronic world. Developmental Review, 30(2), 101-115.

Dickerson, K., Gerhardstein, P., Zack, E., \& Barr, R. (2012). Age-related changes in learning across early childhood: A new imitation task. Developmental Psychobiology, 55(7), 719-732. doi: 10.1002/dev.21068

Donahue, C., \& Schomburg, R. (2017). Technology and interactive media in early childhood programs: What we've learned from five years of research, policy, and practice. Young Children, 72(4), 72-78.

Ebbeck, M., Yim, H., Chan, Y., \& Goh, M. (2015). Singaporean parents' views of their young children's access and use of technological devices. Early Childhood Education Journal, 44(2), 127-134. 
Edwards, C. (1993). The hundred languages of children: The Reggio Emilia approach to early childhood education. Norwood: Ablex Publishing Corporation.

Fedosejeva, J., Boče, A., Romanova, M., Iliško, Dz., \& Ivanova, O. (2018). Education for sustainable development: The choice of pedagogical approaches and methods for the implementation of pedagogical tasks in the Anthropocene Age. Journal of Teacher Education for Sustainability, 20(1), 157-179. doi: 10.2478/jtes-2018-0010

Haugland S. W., \& Wright J. L. (1997). Young children and technology: A world of discovery. Boston, MA: Allyn and Bacon.

Hayes, D., Symington, D., \& Martin, M. (1994). Drawing during science activity in the primary school. International Journal of Science Education, 16, 265-277.

Holbert, R. L., Kwak, N., \& Shah, D. V. (2003). Environmental concern, patterns of television viewing, and proenvironmental behaviors: Integrating models of media consumption and effects. Journal of Broadcasting and Electronic Media, 47(2), 177-196.

Jackson, L. A. (2012). The upside of videogame playing. Games for Health Journal, $1(6), 452-455$.

Keinonen, T., Yli-Panula, Y., Svens, M., Vilkonis, R., Persson, C., \& Palmberg, I. (2014). Environmental issues in the media - studentsk perceptions in the three nordic-baltic countries. Journal of Teacher Education for Sustainability, 16(1), 32-53. doi: https://doi.org/10.2478/jtes-2014-0002

Kirdar, Y. (2007). New consumers in buying behavior advertises children and triggers $4^{\text {th }}$. International Children and Communication Congress II, Istanbul, 607-621.

Kusay, Y., \& Akbayir, Z. (2015). The journey to consumption by digital games: a research on child consumers in terms of learning approach. Akdeniz University Faculty of Communication, 135-154. doi: 10.31123/akil.436885

Lee, S. J., Bartolic, S., \& Vanderwater, E. A. (2009). Predicting children's media use in the USA: Differences in cross-sectional and longitudinal analysis. British Journal of Developmental Psychology, 27, 123-143.

Lieberman, D., Bates, C., \& So, J. (2009). Young children's learning with digital media. Computers in the Schools, 26(4), 271-283. doi:10.1080/07380560903360194

Lieberman, D., Fisk, M., \& Biely, E. (2009). Digital games for young children ages three to six: From research to design. Computers in the Schools, 26(4), 299-313. doi: 10.1080/07380560903360178

Lin, M. Y. (2006). Appreciation and application of picture books. Taipei: Psychological Press.

Lindstrom M., \& Seybold P. B. (2003). Brandchild: Remarkable insights into the minds of today's global kids and their relationships with brands. Istanbul: CSA Public Ajans.

Livingstone, S., Haddon, L., Görzig, A., \& Ólafsson, K. (2011). Risks and safety on the internet: The perspective of European children. London: EU Kids Retrieved from: EUKidsOnlineIIReports/D4FullFindings.pdf

Malchiodi, C. A. (1998). Understanding children's drawings. Istanbul: Epsilon Publishing. Marsh, J., Plowman, L., Yamada-Rice, D., Bishop, J. C., Lahmar, J., Scott, F., Davenport, A., Davis, S., French, K., Piras, M., Thornhill, S., Robinson, P., \& Winter, P. (2015). Exploring play and creativity in preschoolers' use of apps: Final project report. Retrieved from www.techandplay.org 
Moore, H. C. (2017). Look what I made!: Open-Ended apps that spark creativity. Young Children, 72(5), 1-14.

Pagani, L. S., Fitzpatrick, C., Barnett, T. A., \& Dubow, E. (2010). Prospective associations between early childhood television exposure and academic, psychosocial, and physical well-being by middle childhood. Archives of Pediatrics \& Adolescent Medicine, 164(5), 425-431.

Radesky, J., \& Christakis, D. (2016). Increased screen time. Pediatric Clinics of North America, 63(5), 827-839. doi: 10.1016/j.pcl.2016.06.006

Radesky, J., Silverstein, M., Zuckerman, B., \& Christakis, D. (2014). Infant self-regulation and early childhood media exposure. Pediatrics, 133(5), 1172-1178. doi: 10.1542/peds.2013-2367

Richert, R., Robb, M., Fender, J., \& Wartella, E. (2010). Word learning from baby videos. Archives of Pediatrics \& Adolescent Medicine, 164(5), 432-437. doi: 10.1001/archpediatrics

Rideout, V. (2011). Zero to eight: Children's media use in America. Retrieved from https://www.commonsensemedia.org/research/zero-to-eight-childrens-media-use-inAmerica

Rideout, V. (2013). Common sense media. Retrieved from https://www.commonsense media.org/

Rideout, V. (2017). The Common sense census: Media use by kids age zero to eight. San Francisco, CA: Common Sense Media.

Saglam, M. (2011). The study examining family perceptions and problems of children who belongs to families in process of divorce with intervention of pictures (Unpublished master's thesis). Ankara University Graduate School of Natural and Applied Sciences, Ankara.

Salite, I. (2015). Searching for sustainability in teacher education and educational research: Experiences from the Baltic and Black Sea Circle Consortium for educational research. Discourse and Communication for Sustainable Education, 6(1), 21-29.

Sapsaglam, Ö. (2017). Examining the value perceptions of preschool children according to their drawings and verbal expressions: Sample of responsibility value. Education and Science, 42(189), 287-303.

Sapsaglam, Ö. (2018). Social media awareness and usage in preschool children. International Journal of Eurasia Social Sciences, 9(31), 28-746.

Seo, H., Chun, H., Jwa, S., \& Choi, M. (2011). Relationship between young children's habitual computer use and influencing variables on socioemotional development. Early Child Development and Care, 181(2), 245-265. doi: 10.1080/03004430. 2011.536644

Skouteris, H., Do, M., Rutherford, L., Cutter-Mackenzie, A., \& Edwards, S. (2010). Call for research - the consuming child-in-context in unhealthy and unsustainable times. Australian Journal of Environmental Education, 26, 33-45.

Slušnienè, G. (2019). Possibilities for development of emotional intelligence in childhood in the context of sustainable education. Discourse and Communication for Sustainable Education, 10(1), 133-145. doi: https://doi.org/10.2478/dcse-2019-0010

Soper, K. (2007). Re-thinking the 'Good Life'. Journal of Consumer Culture, 7(2), 205229.

Striker, S. (2005). Art education of children. Istanbul: Epsilon Publishing. 
Teichert, L. (2017). To digital or not to digital: How mothers are navigating the digital world with their young children. Language and Literacy, 19(1), 63-76.

Temel, Z. F., \& Dere, H. (1999). Gazi university early childhood teacher's handbook. Istanbul: Ya-Pa Publishing.

Teychenne M., Ball K., \& Salmon J. (2010). Sedentary behavior and depression among adults: A review. International Journal of Behavioral Medicine, 17, 246-254. doi:10.1007/s12529-010-9075-z

Thai, A. M., Lowenstein, D., Ching, D., \& Rejeski, D. (2009). Game changer: Investing in digital play to advance children's learning and health. New York: Joan Ganz Cooney Center. Retrieved from http://www.joanganzcooneycenter.org/pdf/Game Changer FINAL.pdf

Thompson, A., Adair, L., \& Bentley, M. (2013). Maternal characteristics and perception of temperament associated with infant exposure. Pediatrics, 131(2), 390-397. doi:10.1542/peds.2012-1224

UNESCO (2008). The Gothenburg recommendations on education for sustainable development. Retrieved from https://www.chalmers.se/sv/om-chalmers/miljo-ochhallbar-utveckling/tidig-satsning-pa-miljo-och-hallbarhet/Documents/Goteborgs rekommendationerna.pdf

Valkenberg, P. M. (2001). Television and the child' developing imagination. In Singer, D. G., \& Singer, J. L. (Eds.), Handbook of children and the media (pp. 121134). Thousand Oaks, CA: Sage Publications.

Valkenburg, P., \& Piotrowski, J. (2017). Plugged in: How media attract and affect youth. Yale University Press.

Vandewater, E., Rideout, V., Wartella, E., Huang, X., Lee, J., \& Shim, M. (2007). Digital childhood: Electronic media and technology use among infants, toddlers, and preschoolers. Pediatrics, 119(5), 1006-1015. doi: 10.1542/peds.2006-1804

Veisson, M., \& Kabadayi, A. (2018). Exploring the preschool teachers' views on professionalism, quality of education and sustainability: International Study in Estonia and Turkey. Journal of Teacher Education for Sustainability, 20(2), 5-18. doi: https://doi.org/10.2478/jtes-2018-0011

Verenikina, I., \& Kervin, L. (2011). iPads digital play and preschoolers. Не Кирu, 2(5), 4-19.

Vibbert, M. M., \& Meringof, F. L. K. (1981). Children's production and application of story imagery: A cross-medium investigation. Cambridge, MA: Harvard University, Project Zero.

Yildirim, A., \& Simsek, H. (2013). Qualitative research method in Social Science. Ankara: Seckin Publishing.

Correspondence regarding this article should be addressed to Begum Canaslan Akyar, Tarsus University, Mersin. Email: begum.canaslan@metu.edu.tr

and Özkan Sapsaglan, Yildiz Technical University, Istanbul. Email: ozkan@yildiz.edu.tr 